Volume. 2 Nomor. 2

Periode: Juli - Desember 2018; hal. 58-65

p-ISSN : 2580-1112; e-ISSN : 2655-6669

Copyrighr@2018

Penulis memiliki hak cipta atas artikel ini

Jurnal Ilmiah Keperawatan Orthopedi (JIKO)

journal homepage:

https://ejournal.akperfatmawati.ac.id

\title{
Dukungan Keluarga Dengan Penerimaan Ibu Yang Memiliki Anak Down Syndrome Di Rumah Ceria Down Syndrome Jakarta Selatan
}

\author{
Nadira Dwi Artika ${ }^{1}$, Sang Ayu Made Adyani ${ }^{2}$, Diah Ratnawati ${ }^{3}$ \\ Program S1 Keperawatan, Fakultas Ilmu Kesehatan, Universitas Pembangunan Nasional \\ "Veteran" Jakarta
}

\begin{abstract}
Abstrak
Down syndrome merupakan penyebab genetik paling sering pada keterbelakangan mental, Memiliki anak berkebutuhan khusus tentunya menjadi beban berat bagi ibu. Dukungan keluarga merupakan faktor penting dalam menerima keadaan yang dialami ibu. Penelitian ini bertujuan untuk mengetahui hubungan dukungan keluarga dengan penerimaan ibu yang memiliki anak down syndrome di Rumah Ceria Down Syndrome Jakarta Selatan. Desain penelitian ini kuantitatif menggunakan deskriptif analitik dengan pendekatan cross sectional. Teknik pengambilan sampel menggunakan total sampling sebanyak 45 ibu. Analisa bivariat menggunakan uji chi-square. Dari hasil uji statistik chisquare dapat disimpulkan bahwa ada hubungan antara dukungan keluarga dengan penerimaan ibu yang memiliki anak down syndrome ( $p$ value sebesar $0,005<0.05$ ) dan ada hubungan antara dukungan sosial dengan penerimaan ibu yang memiliki anak down syndrome ( $p$ value sebesar $0,15<0,05$ ). Hasil penelitian ini menjadi masukan bagi ibu sehingga memiliki penerimaan diri yang baik agar dapat mempersiapkan pengasuhan yang tepat untuk perkembangan dan pertumbuhan anak maksimal.
\end{abstract}

Kata Kunci: Down Syndrome, Dukungan Keluarga, Penerimaan Diri

\begin{abstract}
Down syndrome is the most common genetic cause of mental retardation in children in need special, has become a heavy burden for the mother. Family support is an important factor in accepting the circumstances experienced by the mother. This research aims to know the relationship of family support with acceptance of mothers who have children of down syndrome at Rumah Ceria Down Syndrome South Jakarta. The design of this study analyzed quantitatively using a descriptive analytic with cross sectional approach. Sampling technique using total sampling of as many as 45. Bivariat analysis using the chi-square test. From the results of the statistical test of chi-square can be concluded that there is a relationship between family support with acceptance of mothers who have down syndrome ( $p$ value of $0.005<0.05$ ). The results of this research into the input for the mother so have yourself a good acceptance in order to prepare an appropriate upbringing for the child so that the child's growth and development.
\end{abstract}

Keywords: Acceptance of The Mother, Down Syndrome, Family Support

1,2,3 e-mail: udek_yani@yahoo.com

Dukungan Keluarga Dengan Penerimaan Ibu Yang Memiliki Anak Down Syndrome..... 


\section{Pendahuluan}

Bagi keluarga kelahiran seorang anak merupakan sebuah anugerah yang diberikan oleh Allah SWT. Kehadiran seorang anak bukan hanya mempererat hubungan keluarga, tetapi juga sebagai penerus dalam keluarga. Anak juga merupakan sebuah harapan.

Setiap orang tua menginginkan dan merasa bahagia ketika melihat anaknya sehat, cerdas dan berkembang dengan sempurna mulai dari bayi sampai dewasa. Namun, tidak semua anak dilahirkan dan tumbuh dalam keadaan normal. Beberapa diantaranya memilikki keterbatasan baik secara fisik ataupun psikis yang telah dialami sejak awal masa perkembangan (Faradina, 2016).

Gangguan yang paling umum dialami ketika bayi adalah gangguan kromosom, atau yang paling sering kita dengar adalah Down Syndrome. Kelainan ini dikarenakan adanya satu ekstra kromosom (bagian sel tubuh yang menentukan pertumbuhan dan perkembangan fisik dan mental karakteristrik manusia) pada penerita.

Hal ini terjadi karena jumlah kromosom yang dimiliki penderita tidak sesuai dengan jumlah kromosom yang dimilikki manusia yang normal. Secara statistik, Down Syndrome adalah sumber gangguan yang terjadi sebesar 5\% dari total kasus tunagrahita. World Health Organization / WHO (2018) mengungkapkan perkiraan insiden down syndrome antara 1 dalam 1.000 hingga 1 dalam 1.100 kelahiran hidup di seluruh dunia, setiap tahun sekitar 3.000 hingga 5.000 anak diahirkan dengan gangguan kromosom ini dan diyakini ada sekitar 250.000 keluarga Amerika Serikat yang terkenda dampak down syndrome.

Hasil sensus penduduk 2010, dari 237 juta penduduk Indonesia, jumlah anak berkebutuhan khusus usia sekolah (5-18 tahun) ada 355.859 anak. 74,6\% dari jumlah itu, belum memperoleh layanan pendidikan (Syahputra, Wakhid, \& Choiriyyah,2017). Selain itu di DKI Jakarta, terdapat $16,52 \%$ dinyatakan anak berkebutuhan khusus dari 3.215 siswa sekolah dasar (Rahayuningsih \& Andriani, 2011).

Memiliki anak berkebutuhan khusus tentunya menjadi beban berat bagi orang tua baik secara fisik maupun mental. Beban berat tersebut membuat reaksi emosional seperti shock, mengalami kegoncangan batin, terkejut dan tidak mempercayai kenyataan yang menimpa anaknya.

Orang tua yang memiliki anak berkebutuhan khusus di tuntut untuk terbiasa menghadapi peran yang berbeda dari sebelumnya (Wardani, et al, 2012), kenyataan ini dapat memberikan pengaruh pada dukungan orang tua yang memilikki anak down syndrome.

Ibu yang frekuensi bersama anaknya lebih sering daripada ayah dalam pengasuhan anak, ibu lebih membutuhkan dukungan sosio-emosional dalam waktu yang lama dan lebih banyak informasi tentang kondisi anak serta dalam merawat anak karena membutuhkan perhatian lebih banyak (Wijayanti, 2015).

Ibu merupakan seseorang yang rentan terhadap masalah penyesuaian. Hal ini dikarenakan mereka berperan langsung dalam kelahiran anak. Pandangan yang terbentuk pada ayah ataupun ibu juga sering menyebabkan kesenjangan antara kegembiraan setelah masa penantian pada masa kehamilan dengan realitas keadaan anaknya (Mangunsong, 2016).

Dukungan keluarga merupakan faktor penting dalam menerima keadaan yang dialami ibu yang memilikki anak down syndrome, dukungan ini menjadi dukungan yang utama bagi ibu karena dukungan keluarga ini dapat berasal dari dukungan pasangan hidup (suami), dukungan dari anak (saudara dari anak yang mengalami down syndrome), orang tua dan mertua (Fadilah, 2015).

$$
\text { Hadirnya dukungan yang }
$$
diperoleh akan membuat ibu tidak merasa tertekan dan mengalami stres saat 
mengasuh anaknya (Megasari \& Kristiana, 2016).

Hasil penelitian Fadilah (2015) sebanyak 38 responden $(95,0 \%)$ dari 40 responden memiliki dukungan keluarga dalam kategori baik dan memilikki penerimaan diri dalam kategori baik sejumlah 34 responden $(85,0 \%)$.

Hal tersebut dibuktikan oleh penelitian Megasari dan Kristiana (2016) mengatakan bahwa dari 51 ibu yang memilikki anak down syndrome menunjukkan bahwa sebesar 41 responden $(80,39 \%)$ memiliki dukungan sosial suami yang tinggi dan 37 responden $(72,54 \%) \quad$ memiliki penerimaan diri yang tinggi.

Hal ini membuktikan bahwa mayoritas subjek penelitian memilikki penerimaan tinggi yang disebabkan karena istri mendapatkan dukungan yang suami bermanfaat untuk istri.

Orang tua dengan mudah mendapat kritik dari orang lain tentang masalah mereka dalam menghadapi kondisi anak. Selain itu, respon negatif yang diberikan lingkungan kepada anaknya yang down syndrome juga menjadi masalah yang sering ditemui dalam kehidupan sehari-hari (Wijayanti, 2015).

Masyarakat kadang-kadang bisa menjadi lebih kejam melalui respon mereka terhadap seseorang yang memilikki kebutuhan khusus, terutama pada mereka yang kecacatannya mudah dapat dilihat. Maka dari itu, dukungan sosial sangat diperlukan. Perlakuan lingkungan sosial terhadap seseorang akan membentuk tingkah laku orang tersebut.

Hal ini membuat seseorang yang mendapatkan perlakuan dari lingkungan sosial yang mendukung akan dapat menerima dirinya sendiri dengan lebih baik. Tanpa adanya dukungan sosial menyebabkan Ibu yang memiliki anak down syndrome akan menjadi sulit menerima dirinya (Ikromah, 2015).

Hasil penelitian Syahputra,
Wakhid dan Choiriyyah (2017)

mengatakan bahwa adanya hubungan yang signifikan antara hubungan dukungan sosial dengan penerimaan orang tua anak down syndrome. Diantara 49 responden dalam kategori baik yaitu sejumlah 38 orang $(77,6 \%)$, sedangkan dukungan sosial dengan kategori kurang yaitu sejumlah 11 orang $(22,4 \%)$.

Dukungan sosial ini dipengaruhi karena responden selalu merasa nyaman saat teman-teman bertanya dengan keadaan anak, teman-temannya juga peduli terhadap suasana hati responden saat sedih ataupun pada saat kesulitan.

Selain itu, responden menyatakan bahwa teman dan kerabat memberikan pinjaman uang ketika anak sakit dan memberi informasi tentang tahap perkembangan, masalah yang sering terjadi pada anak down syndrome.

Berdasarkan hasil wawancara dengan 5 orang tua yang memiliki anak down syndrome mengatakan bahwa reaksi awal saat mengetahui anaknya memiliki kelainan adalah menangis, bingung dan marah karena mengapa hal itu terjadi pada anaknya.

Kedua ibu mengatakan keluarga dari suami kurang menerima keberadaan anaknya dan mempermasalahkan hal tersebut, keluarga juga jarang membantu bila ibu kesulitan dalam mengurus anak. Dua orang ibu mengatakan memiliki masalah dengan lingkungan sekitarnya karena tetangga mengatakan anaknya tampak aneh.

Tiga ibu mengatakan tidak suka jika teman kerjanya berkomentar buruk tentang anaknya, selain itu ketika ibu membawa anaknya di tempat ramai seperti mall pandangan aneh orang-orang ketika melihat fisik anaknya membuat ibu merasa tidak nyaman.

\section{Metode Penelitian}

Jenis penelitian ini adalah kuantitatif dengan desain deskriptif analitik, menggunakan metode cross sectional, dimana penelitian yang dilakukan dengan cara pengumpulan data sekaligus pada suatu saat, tiap subjek 
penelitian hanya diobservasi sekali dalam pengukuran terhadap status karakter atau variabel subjek pada saat pemeriksaan (Notoatmodjo, 2012).

Teknik pengambilan sampel dalam penelitian ini menggunakan teknik nonprobability yaitu sampel jenuh atau sering disebut total sampling. Sampel jenuh adalah teknik penentuan sampel dengan cara mengambil seluruh anggota populasi sebagai responden atau sampel (Notoatmodjo, 2012).

Responden pada penelitian ini adalah ibu yang memiliki anak dengan Down Syndrome, bisa membaca dan menulis, dan sehat jasmani dan rohani. Peneliti memberikan penjelasan penelitian sebelum responden menandatangani informed consent. Peneliti mengahargai keputusan responden untuk menolak atau berhenti saat penelitian berlangsung.

\section{Hasil Penelitian}

\section{Karakteristik Responden}

Tabel 1 Distribusi Frekuensi Karakteristik Usia Responden Di Rumah Ceria Down Syndrome Jakarta Selatan, Tahun $2018(\mathrm{n}=45)$.

\begin{tabular}{ccc}
\hline Usia & Frekuensi & Presentase \% \\
\hline $20-30$ & 5 & $11.1 \%$ \\
$31-40$ & 18 & $40,0 \%$ \\
$41-50$ & 17 & $37,8 \%$ \\
$51-60$ & 5 & $11,1 \%$ \\
Total & 45 & $100 \%$ \\
\hline
\end{tabular}

Berdasarkan tabel 1 diketahui bahwa sebanyak 18 orang (40\%) berusia $31-40$ tahun, 17 orang $(37,8 \%)$ berusia 41-50 tahun dan 5 orang $(11,1 \%)$ responden berusia 20-30 tahun dan 51-60 tahun.

Tabel 2 Distribusi Frekuensi Usia Anak Responden Rumah Ceria Down Syndrome Jakarta Selatan, Tahun 2018 $(\mathrm{n}=45)$.

\begin{tabular}{ccc}
\hline Usia & Frekuensi & Presentase \% \\
\hline $0-4$ & 23 & $51,1 \%$ \\
$5-11$ & 16 & $36,6 \%$ \\
$12-16$ & 2 & $4,4 \%$
\end{tabular}

\begin{tabular}{ccc}
\hline Usia & Frekuensi & Presentase \% \\
\hline $17-25$ & 4 & $8,9 \%$ \\
Total & 45 & $100 \%$ \\
\hline
\end{tabular}

Tabel 2 menunjukkan bahwa sebanyak 23 anak $(51,1 \%)$ berusia $0-4$ tahun, 16 anak $(36,6 \%)$ berusia 5-11 tahun, 2 anak $(4,4 \%)$ berusia 12-16 tahun, dan 4 anak $(8,9 \%)$ berusia 17-25 tahun.

Tabel 3 Distribusi Frekuensi Pendidikan Responden di Rumah Ceria Down Syndrome Jakarta Selatan, tahun 2018 $(n=45)$.

\begin{tabular}{ccc}
\hline Pendidikan & Total & Presentase\% \\
\hline SD & 1 & $2,2 \%$ \\
SMP & 0 & $0 \%$ \\
SMA & 13 & $28,9 \%$ \\
PT & 31 & $68,9 \%$ \\
Total & 45 & $100 \%$ \\
\hline
\end{tabular}

Berdasarkan tabel 3 diketahui bahwa sebagian besar responden berpendidikan PT yaitu sebanyak 31 orang $(68,9 \%)$

Tabel 4 Distribusi Frekuensi Pekerjaan Responden di Rumah Ceria Down Syndrome Jakarta Selatan, tahun 2018 $(n=45)$.

\begin{tabular}{ccc}
\hline Pekerjaan & Total & Presentase \% \\
\hline Tidak & 29 & $64,4 \%$ \\
Bekerja & & \\
Swasta & 12 & $26,7 \%$ \\
Wiraswasta & 0 & $0 \%$ \\
PNS & 4 & $8,9 \%$ \\
Total & 45 & $100 \%$ \\
\hline
\end{tabular}

Berdasarkan tabel 4 diketahui bahwa mayoritas responden tidak bekerja atau sebagai ibu rumah tangga/IRT yaitu sebanyak 29 orang $(64,4 \%)$.

\section{Dukungan Keluarga}

Tabel 5 Distribusi Frekuensi Dukungan Keluarga di Rumah Ceria Down Syndrome Jakarta Selatan, tahun 2018 $(n=45)$. 


\begin{tabular}{ccc}
\hline $\begin{array}{c}\text { Dukungan } \\
\text { Keluarga }\end{array}$ & Total & Presentase\% \\
\hline Baik & 23 & $51,1 \%$ \\
Kurang Baik & 22 & $48,9 \%$ \\
Total & 45 & $100 \%$ \\
\hline
\end{tabular}

Berdasarkan tabel 5 diketahui bahwa sebanyak 23 orang $(51,1 \%)$ memiliki dukungan keluarga baik, dan 22 orang $(48,9 \%)$ memiliki dukungan keluarga kurang baik.

\section{Penerimaan Diri}

Tabel 6 Distribusi Frekuensi Penerimaan Diri Ibu di Rumah Ceria Down Syndrime Jakarta Selatan, tahun $2018(n=45)$.

\begin{tabular}{ccc}
\hline $\begin{array}{c}\text { Penerimaan } \\
\text { Diri }\end{array}$ & Total & Presentase\% \\
\hline Baik & 25 & $55,6 \%$ \\
Kurang Baik & 20 & $44,4 \%$ \\
Total & $\mathbf{4 5}$ & $\mathbf{1 0 0 \%}$ \\
\hline
\end{tabular}

Berdasarkan table 6 diketahui bahwa sebanyak 25 orang $(55,6 \%)$ memiliki penerimaan diri baik, sedangkan responden yang memiliki penerimaan diri yang kurang baik sebanyak 20 orang $(44,4 \%)$.

\section{Hubungan dukungan keluarga dengan} penerimaan diri

Tabel 9 Hubungan Dukungan Keluarga Dengan Penerimaan Ibu yang Memiliki Anak Down Syndrome di Rumah Ceria Down Syndrome Jakarta Selatan, tahun $2018(\mathrm{n}=45)$.

keluarga yang kurang baik yaitu sebanyak $51,1 \%$.

Keluarga adalah kumpulan dua orang atau lebih yang hidup bersama dengan keterikatan aturan emosional dimana individu mempunyai peran masing-masing dan merupakan bagian dari keluarga (Efendi \& Makhfuldi, 2009).

Dukungan keluarga adalah proses yang terjadi semasa hidup, dengan sifat dan tipe dukungan yang bervariasi pada masing-masing tahap siklus kehidupan keluarga sehingga setiap anggota keluarga merasa ada yang memperhatikan (Friedman, Bowden \& Jones, 2010). Dukungan keluarga dapat berupa dukungan instrumental, informasional, penilaian dan emosional.

Dukungan instrumental merupakan sumber pertolongan praktis dan konkrit seperti dukungan uang. Dukungan berupa uang dapat membantu individu dalam mengatasi masalah finansial karena harus menjalani pengobatan secara rutin (Utami, 2013).

Dukungan informasional berfungsi sebagai sebuah kolektor dan disseminator (penyebar informasi). Menurut Syahputra, Wakhid, dan Choiriyyah (2017) keluarga selalu memberikan informasi tentang perkembangan, cara merawat dan memberikan informasi masalah yang sering terjadi pada anak down syndrome.

Keluarga merupakan tempat

\begin{tabular}{ccccccccc}
\hline \multirow{2}{*}{$\begin{array}{c}\text { Dukun } \\
\text { gan } \\
\text { keluarg } \\
\text { a }\end{array}$} & \multicolumn{2}{c}{$\begin{array}{c}\text { Kurang } \\
\text { Baik }\end{array}$} & & Baik & $\begin{array}{c}\mathrm{T} \\
\text { ot } \\
\text { al }\end{array}$ & $\begin{array}{c}\text { OR } \\
(95 \% \mathrm{CI})\end{array}$ & $\begin{array}{c}\mathrm{P} \text { V V } \\
(\mathrm{P}<\end{array}$ \\
\cline { 2 - 8 } & $\mathrm{n}$ & $\%$ & $\mathrm{n}$ & $\%$ & $\mathrm{n}$ & $\%$ & \\
\hline Kurang & 15 & 75 & 7 & 28 & 22 & 48 & 7,714 \\
Baik & & & & & & & $(2,027-$ \\
Baik & 5 & 25 & 18 & 72 & 23 & 51 & 29,362 \\
Jumlah & 20 & 100 & 25 & 100 & 45 & 100 & ) \\
\hline
\end{tabular}
individu bercerita dan mengeluarkan P Vkeluhan-keluhan apabila individu < 月, seseorang menganggap keluarga adalah tempat yang nyaman untuk berbagi kebahagiaan, menghadapi persoalan dan harapan hidup.

Keluarga menyempatkan diri untuk menyediakan kebutuhan yang

\section{Pembahasan}

\section{Dukungan Keluarga}

Berdasarkan hasil analisis distribusi frekuensi pada tabel 5 diketahui bahwa dukungan keluarga yang baik lebih besar daripada dukungan dibutuhkan dan selalu menyisihkan waktu disetiap kesibukan yang mereka lakukan (Sangian, Wowling \& Malara, 2011). 


\section{Penerimaan Diri}

Berdasarkan hasil analisis distribusi frekuensi pada tabel 6 diketahui bahwa sebanyak 55,6\% memiliki penerimaan diri baik dan penerimaan diri kurang baik sebanyak $44,4 \%$.

Penerimaan diri pada ibu yang memiliki anak down syndrome tidaklah mudah, karena orang tua khususnya ibu masih beranggapan kalau adanya anak yang mengalami down syndrome menjadi kekurangan atau sisi negatif dalam hidupnya (Megasari \& Kristiana, 2016).

Menurut Knussen dan Sloper (1992, dalam Dabrowska \& Pisula, 2010) bahwa ibu yang memiliki anak dengan disabilitas perkembangan mengalami kesulitan besar karena masalah perilaku anak, ketergantungan pada perawatan, kecemasan dan masalah dalam komunikasi.

Hasil penelitian yang dilakukan oleh Syahputra, Wakhid, dan Choiriyyah (2017) tentang penerimaan ibu yang memiliki anak down syndrome dari 49 responden, 41 diantaranya memiliki penerimaan yang baik, hal ini dikarenakan orang tua yang menerima anak apa adanya menaruh perhatian dan penerimaan tak bersyarat.

Berbeda dengan penelitian Wijayanti (2015) hasil wawancara yang dilakukan bahwa orang tua menginginkan anaknya bisa normal seperti anak lainnya, merasa sedih ketika apa yang diharapkan tidak sesuai dengan yang terjadi.

Orang tua merasa bahwa anaknya tertukar dengan anak lain dan sudah melakukan tes DNA yang ternayata golongan darahnya sama dengan neneknya membuatnya merasa tidak diterima. Hal ini dikarenakan ibu tidak bahagia dan merasakan sikap negatif selama pengasuhan anaknya.

\section{Hubungan Dukungan Keluarga dengan Penerimaan Diri Ibu}

Berdasarkan hasil uji statistik didapatkan nilai $p$ value sebesar $0,005 p$ value < 0,05$)$ yang berarti $p$ value < sehingga Ho ditolak dan $\mathrm{Ha}$ diterima hasil berarti ada hubungan dukungan keluarga dengan penerimaan diri ibu yang memiliki anak down syndrome di rumah ceria down syndrome Jakarta Selatan.

Hasil uji analisis juga mendapatkan nilai odd ratio $(\mathrm{OR})=$ 7,714 (dibulatkan menjadi 8) dan CI 95\% $=2,027-29,362$. Hasil analisa tersebut menunjukan bahwa OR > 1, artinya jika dukungan keluarga baik berpeluang 7,714 kali memiliki penerimaan diri ibu lebih baik.

Dukungan keluarga merupakan faktor penting dalam menerima keadaan yang dialami ibu yang memilikki anak down syndrome, dukungan ini menjadi dukungan yang utama bagi ibu karena dukungan keluarga ini dapat berasal dari dukungan pasangan hidup (suami), dukungan dari anak (saudara dari anak yang mengalami down syndrome), orang tua dan mertua (Fadilah, 2015). Apabila ibu kurang mendapatkan dukungan dapat menimbulkan stress bagi keluarga.

Stress yang dialami orang tua dapat secara signifikan mempengaruhi penyesuain orang tua untuk merawat anak dengan berkebutuhan khusus (Dabrowska \& Pisula, 2010). Suksesnya adaptasi tergantung pada kemampuan keluarga mengatasi stress.

Menurut Dabrowska dan Pisula (2010) sumber dukungan dari keluarga sangat berguna dalam adaptasi keluarga yang memilik anak berkebutuhan khusus. Hadirnya dukungan yang diperoleh akan membuat ibu tidak merasa tertekan dan mengalami stres saat mengasuh anaknya (Megasari \& Kristiana, 2016).

Pengasuhan penerimaan orang tua dicirikan dengan curahan kasih sayang orang tua kepada anak-anak baik secara fisik maupun verbal. Ibu mengekspresikan kasih sayangnya melalui pelukan dan ciuman di pipi atau di kening.

Secara verbal ibu senantiasa mengekspresikan kasih sayang dan perhatian melalui penghargaan, pujian, 
menggunakan kata-kata dukungan untuk maju, berjuang dan bersemangat (Syahputra, Wakhid, \& Choiriyyah, 2017).

\section{Kesimpulan}

Berdasarkan hasil penelitian, maka dapat disimpulkan bahwa ada hubungan signifikan antara dukungan keluarga dengan penerimaan diri ibu yang memiliki anak Down Syndrome di Rumah Ceria Down Syndrome Jakarta Selatan.

Bagi keluarga agar memberikan dukungan kepada ibu seperti bertukar pikiran dan merasakan simpati tentang apa yang dirasakan ibu dalam merawat anak. Dukungan keluarga lebih banyak didapatkan dari keluarga besar, sehingga diharapkan penelitian selanjutnya memasukkan anggota keluarga besar dalam sampel penelitian.

\section{Daftar Pustaka}

[1] Dabrowska, A., \& Pisula, E. (2010). Parenting stress and coping styles in mothers and fathers of preschool children with autism and Down syndrome. Journal of Intellectual Disability Reseach. Vol. 54 part 3 pp 266-280.

[2] Efendi, F., \& Makhfuldi., (2009). Keperawatan kesehatan komunitas teori dan praktik dalam keperawatan. Penerbit Salemba Medika: Jakarta.

[3] Fadilah, S., (2015). Hubungan dukungan keluarga dengan penerimaan diri ibu dari anak autis di Sekilah Luar Biasa Negri 1 Bantul Yoyakarta. Naskah publikasi skripsi. Yogyakarta: STIKES 'Aisyiyah

[4] Faradina, N. (2016). Penerimaan diri pada orang tua yang memilikki anak berkebutuhan khusus. eJournal Psikologi vol. 4, no. 4, hal. 386-396. Universitas Mulawarman.

[5] Friedman, M., Bowden, V., \& Jones, E., (2010) . Buku ajar keperawatan keluarga.Penerbit Buku Kedokteran EGC: Jakarta.

[6] Ikromah, L., (2015). Pengaruh preceived behavoral control, dukungan sosial, dan religiusitas terhadap penerimaan diri orang tua yang memiliki anak down syndrome. Skripsi. Universitas Islam Negri Syarif Hidayatullah Jakarta.

[7] Mangunsong, F. (2016). Psikologi dan pendidikan anak berkebutuhan khusus, Jilid Kedua. LPSP3 UI: Depok.

[8] Megasari, I., \& Kristiana, I., (2016). Hubungan antara dukungan sosial suami dengan penerimaan diri ibu yang memiliki anak down syndrome di Semarang. Jurnal Empati, vol. 5, no. 4, hal. 653-659. Universitas Diponegoro Semarang

[9] Notoatmodjo, S., (2012). Metodologi penelitian kesehatan. Jakarta: Rineka Cipta.

[10] Rahayuningsih, S.I., \& Andriani, R., (2011). Gambaran penyesuaian diri orang tua yang memilikki anak berkebutuhan khusus di Banda Aceh. Jurnal keperawatan. Hal: 167-175. Banda Aceh: Universitas Syiah Kuala.

[11] Sangian, L., Wowiling, F., \& Malara, R., (2017). Hubungan dukungan emosional keluarga dengan penerimaan diri pada lansia di Desa Watutumou III. eJurnal Keperawatan vol. 5, no. 2, hal. 1-8. Universitas Sam Ratulangi Manado.

[12] Syahputra, H., Wakhid, A., \& Choiriyyah, Z. (2017). Hubungan antara dukungan sosial dengan penerimaan orang tua anak down syndrome di SLB Kabupaten Semarang. Jurnal keperawatan. Hal: 1-11. Jawa Tengah: Universitas Ngudi Waluyo.

[13] Utami, N., (2013). Hubungan antara dukungan sosial keluarga dengan penerimaan diri individu yang mengalami Asma. Jurnal 
Psikologi vol. 1, no. 1, hal. 12-21.

Universitas Udayana.

[14] .WHO, (2018). Genomic resource centre gens and human disease.

[15] Wijayanti, D. (2015). Subjective well-being dan penerimaan diri ibu yang memilikki anak down syndrome. eJournal psikologi, vol. 4, no.1, hal. 120-130. Kalimantan

Timur: Universitas Mulawarman 